\title{
Interpretation of the Prohibition of Torture: Making Sense of 'Dignity' Talk
}

\author{
Elaine Webster ${ }^{1}$
}

Published online: 29 April 2016

C The Author(s) 2016. This article is published with open access at Springerlink.com

\begin{abstract}
The right not to be subjected to torture, cruel, inhuman or degrading treatment or punishment is invariably associated with 'human dignity'. The idea of dignity plays some role in this right's interpretation, although the content of the idea in this context, as in others, is unclear. Making sense of the dignity idea involves a number of challenges. These challenges give rise to the methodological-type question at the heart of this article: how should human rights lawyers go about articulating the content of 'dignity'? The article proposes, and models, a methodological approach in response. Its core argument is that human rights law needs the vocabulary provided by theorizations of dignity but that these theorizations should be anchored in authoritative human rights jurisprudence. It argues that this approach can help make sense of the dignity idea in a way that facilitates a richer understanding of its influence on interpretation.
\end{abstract}

Keywords Dignity $\cdot$ Torture $\cdot$ Inhuman treatment · Degrading treatment · Interpretation

\section{Introduction}

The right not to be subjected to torture is paradigmatic of the international human rights regime's aspiration to protect human dignity. ${ }^{1}$ The prohibition of torture and associated harms is described as having "a particularly prominent role in upholding human dignity" (Feldman 1999, 690), as "underpinned" by the idea of human

\footnotetext{
${ }^{1}$ United Nations, Charter of the United Nations, Preamble, 26 June 1945; United Nations, Universal Declaration of Human Rights, Preamble, 10 December 1948; (for an overview see, e.g. Dicke 2003).

Elaine Webster

elaine.webster@strath.ac.uk
}

1 School of Law, Faculty of Humanities and Social Science, University of Strathclyde, Graham Hills Building, Level 7, 50 George St., Glasgow G1 1QE, UK 
dignity (Cassese 1991, 143) and as concerned with harm that is "manifestly contrary to human dignity" (Costa 2013, 400). Yet, it has also been observed that dignity $^{2}$ is not the "whole story of the wrongness of torture" (Waldron 2012, 143). There has been little consideration of the impact of the dignity/torture pairing on interpretation of the terms that constitute the right and the consequent scope of protection afforded by it to individuals who claim to be victims of its violation.

This article begins to address the under-theorized relationship between the dignity idea and the right not to be subjected to torture, from the perspective of human rights law. It asks how, in interpreting the right not to be subjected to torture, ${ }^{3}$ human rights lawyers should make sense of the content of its 'underpinning' dignity idea in a way that can illuminate its interpretive scope? The interpretive scope of this right has long been, and continues to be, a question of great significance. The article begins by illustrating this point. It then describes the challenges of making sense of dignity's meaning, which give rise to the central methodological-type question: where should human rights lawyers look to identify the relevant content of the idea of dignity and how should these interpreters ${ }^{4}$ go about articulating this content? It puts forward a methodology for responding to this question, described as a form of 'constructive' human rights interpretation. The following section models this methodology to offer an example of how it might be applied. The first part details how ideas about dignity play out in one instance of application of the right and asks what kinds of harm the right is being used to protect against. It uses the example of Article 3 of the European Convention on Human Rights (ECHR). Article 3 ECHR is invariably cited as an example of the dignity idea's use in legal adjudication (see, e.g. McCrudden 2008, 19). The European Court of Human Rights (ECtHR; the Court) has generated the largest body of case law and principles on the prohibition of torture, and although the language of dignity is neither explicit in the ECHR, nor in the text of Article 3 , it is frequently invoked by the Court in the interpretation of both. For these reasons, Article 3 jurisprudence forms the case study for identifying the relevant content of the idea of dignity. The second part of this section, addressing both human rights lawyers and dignity scholars, engages with some dignity literature to demonstrate how the case-study findings can be orientated within theoretical perspectives.

In summary, the article articulates the complexity of the question - of how interpreters should go about making sense of the dignity idea - and demonstrates how this complexity can be overcome by pursuing a dynamic methodology that is anchored in practice and mediates practical and theoretical perspectives. It argues that human rights law needs the vocabulary provided by theorizations of dignity and that, at the same time, theorizations of dignity should be viewed from within the limits of human rights jurisprudence if they are to make a practicable impact on interpretation. Human rights lawyers, in particular authoritative human rights interpreters (courts and monitoring bodies), are not necessarily well-placed to undertake exploratory engagement with human dignity theory; this is not a criticism but a feature of the legal role (Nussbaum makes a similar point discussing emotional concepts in adjudication contexts; see 2004, 67-68). Such human rights

\footnotetext{
${ }^{2}$ This article makes no conceptual distinction between the terms 'dignity' and 'human dignity'.

${ }^{3}$ References to the right not to be subjected to torture, or to the prohibition of torture, are used as a way of succinctly referring to torture, cruel, inhuman and degrading treatment or punishment; this form of expression does not intend to diminish the significance of the 'associated' harms.

${ }^{4}$ The term 'interpreters' might refer to any actor with a stake in a right's interpretation, but its use herein is restricted to human rights lawyers (practitioners and scholars).
} 
interpreters, as well as those who do engage with theorizations of the dignity idea, can benefit from the insights of dignity theorists. This article advocates an approach that can allow human rights interpreters and dignity theorists to make sense of the content of the dignity idea in a conceptually nuanced, useable way, in turn helping to realize the dignity idea's contribution to interpretation of the right not to be subjected to torture. ${ }^{5}$

\section{Dignity and Interpretation of the Prohibition of Torture}

Interpreters understand the terms torture, cruel, inhuman and degrading to express harms $^{6}$ that are antithetical to dignity protection. They assert or implicitly assume that the right should protect against harm to dignity in some 'direct' or 'basic' sense. Inquiring into the content of the idea of dignity can provide a resource for evaluating this right's interpretive scope.

When legal interpreters find that a particular harm falls within the scope of one or more of the terms torture, cruel, inhuman and/or degrading treatment/punishment, this interpretive inclusion activates special practical and symbolic consequences: In practical terms, it is the first step towards recognizing harm that a state cannot excuse or justify within the human rights framework; in symbolic terms, it is an acknowledgment that an individual's suffering has been or would be particularly grave. These special consequences mean that interpretation of the right assumes special significance. The meanings of (and boundaries between) the forms of harm within the right have in recent years been most prominently questioned in the USA, ${ }^{7}$ and such interpretive concerns are longstanding: Dayan notes that, in a response to the UN Committee Against Torture, the USA maintained that a reservation to the 1984 Convention Against Torture and Other Cruel, Inhuman or Degrading Treatment or Punishment remained motivated by the ambiguity of the terms cruel, inhuman or degrading treatment (Dayan 2007, 78-82). These 'other' forms of harm have traditionally been explored less than the interpretation of torture. ${ }^{8}$ The interpretation of the term torture is well developed (on the basis of the definition in the Convention Against Torture), but interpreters continue to challenge even this relatively detailed understanding, for example, in its restriction to the acts of public officials. ${ }^{9}$ The evolution

\footnotetext{
${ }^{5}$ It might also be argued that dignity theory needs human rights law, in the sense that human rights jurisprudence could illuminate wider social and philosophical understandings of the dignity idea (see Cane's analysis of the idea of responsibility, where he argues that law has something unique to say about moral concepts like responsibility because of the particular characteristics, and special position, of the social institution of law (Cane 2002). It has been suggested that international human rights discourse has "reshaped" the dignity idea (Donnelly 2015, 14), and human rights law is commonly perceived as the framework for the recent dignity "revolution" (Barak 2015, 34). Such an argument is not an integral part of the present article, which focuses on interpretation of the prohibition of torture.

6 This article uses the term 'harm' and 'dignity harm' throughout. The terminology of harm might be interrogated, but it has been chosen as the most helpful broad, non-specific and succinct way of encompassing a range of expressions, including offenses to dignity, hurt to dignity, violations of dignity and so on.

7 The scope of the different forms of harm was referred to in one of the US 'torture memos' (see Bybee Memorandum, Office of Legal Counsel, U.S. Department of Justice, to Alberto R. Gonzales, Counsel to the President, Re: Standards of Conduct for Interrogation under 18 U.S.C. $\S 2340-2340$ A, 01 August 2002).

${ }^{8}$ Recent examples discussing the other forms of harm include Murtagh (2012), Waldron (2010) and Webster (2011).

${ }^{9}$ For a recent discussion of the prohibition of torture and harm brought about by non-state actors in the context of trafficking, see McGregor (2014).
} 
in the interpretation of the right to date is remarkable - it now encompasses a broad range of circumstances, from harms like corporal punishment ${ }^{10}$ to mental suffering caused to next of kin by authorities' reactions to disappearances. ${ }^{11}$ Interpretive questions applied to the right not to be subjected to torture, cruel, inhuman or degrading treatment or punishment are ongoing. As the right's interpretation continues to mature across the international and regional protection systems, the need for a nuanced appreciation of the conceptual boundaries of this absolute, fundamental right will grow in importance.

Human rights interpreters universally acknowledge a link between this right and the idea of human dignity. They also link other rights to the idea of human dignity ${ }^{12}$ but tend to use as their primary example the right not to be subjected to torture (e.g. Andorno 2009, 229; Gearty 2005, 94; Waldron 2013, 4). Interpreters recognize the inclusion of dignity language alongside the prohibition of torture and associated harms in international and regional instruments ${ }^{13}$ and invoke it in interpretation. ${ }^{14}$ These connections, recognized and affirmed by interpreters, suggest that an interpretive link exists between the idea of dignity and the kind of harm that counts as torture, cruel, inhuman or degrading. It must be presumed that this interpretive link can have tangible consequences in individual claims before human rights monitoring bodies and courts. To explore the influence of the dignity idea on the scope of protection afforded by the absolute prohibition of torture, cruel, inhuman or degrading treatment or punishment, interpreters need to understand its relevant content.

\section{The Challenge of Dignity's Meaning}

Human rights law does not give an obvious response to the question of what human dignity means, and the large, growing body of scholarship on dignity gives a sense of the vast range, and conceptual richness, of possible responses to questions about meaning.

Human rights jurisprudence either refers to the term dignity only implicitly, or explicitly but without elaboration. Although case law harbours the idea, it does not

\footnotetext{
${ }^{10}$ African Commission on Human and Peoples' Rights, Curtis Francis Doebbler/Sudan, Comm. No. 236/00, 04 May 2003.

${ }^{11}$ Inter-American Court of Human Rights, González et al. (“Cotton Field”) v. Mexico, Judgment of 16 November 2009, para. 424.

${ }^{12}$ See overview given by, e.g. McCrudden (2008, 687-694), including capital punishment, protection of private life, freedom from discrimination and socio-economic conditions.

${ }^{13}$ Organisation of American States, American Convention on Human Rights, 1969, Article 5(2); Organisation of African Unity, African Charter on Human and Peoples' Rights, 1981, Article 5; United Nations General Assembly, Convention Against Torture and Other Cruel, Inhuman or Degrading Treatment or Punishment, 1984, Preamble.

${ }^{14}$ See, e.g. the following: African Commission on Human and Peoples' Rights, Sudan Human Rights Organisation \& Centre on Housing Rights and Evictions (COHRE)/Sudan, Comm. No. 279/03-296/05, 27 May 2009, e.g. para. 164; African Commission on Human and People's Rights, Gabriel Shumba v Republic of Zimbabwe, Comm. No. 288/2004, 02 May 2012, para. 164; UN Human Rights Committee, Postovoit v. Ukraine, Comm. No. 1405/2005, 110th Session 2014, para. 9.3; UN Human Rights Committee, General Comment No. 20: Article 7, Forty-fourth session (1992), para. 2; Committee Against Torture, Concluding Observation, El Salvador, CAT/C/SLV/CO/2, 09 December 2009, para. 22; Committee Against Torture, Concluding Observation, Andorra, CAT/C/AND/CO/1, 20 December 2013, para. 18; European Court of Human Rights, Tyrer v. United Kingdom, judgment of 25 April 1978, Series A, no. 26, para. 33.
} 
make its substance transparent. Individual claims tend to show little conceptual engagement with the content of the idea of dignity, following the general trend of international human rights law. This regime does not give an express statement of the content of the idea of dignity in the text of its international or regional instruments despite according the idea a key place in its genesis; as Oscar Schachter wrote, dignity's "intrinsic meaning has been left to intuitive understanding [...]" (Schachter 1983, 849). There is no discernible unified understanding of this idea in the drafting history of the key international instruments that have made it foundational within human rights discourse (Beitz 2013, 265-270). As such, interpreters must look for an understanding of the idea of dignity that fits - with hindsight — the international human rights regime as it has come to take shape. This will be an understanding of the dignity idea that can help to make sense of its relationship to individual entitlements within the body of international human rights law (Beitz 2013, 261-268). Interpreters need something more than what is visible in existing human rights instruments.

Broader sources of insight into the meaning of the dignity idea inhibit human rights interpreters' search for meaning in a different way. Interpreters might look to the way that the idea is understood and articulated beyond human rights jurisprudence, ${ }^{15}$ but this is a complex picture. The meaning of the idea has been described as abstract and perplexing; Luban, for example, has written "notoriously $[. .$.$] human dignity is a vague$ and multiply ambiguous concept [...]" (Luban 2015, 274). In theoretical dignity literature, which has greatly expanded in recent decades, ${ }^{16}$ interpreters will find the dignity idea located within various discourses and constituted by overlapping dimensions pertaining to both substance and function (e.g. Kass 2008; Meltzer Henry 2011; Neal 2012; Riley 2010; Shultziner 2007).

There is another strand to the complexity of the dignity idea's meaning: Its meaning might seem quite clear as it pertains, not to human rights law in general but to the prohibition of torture, cruel, inhuman or degrading treatment or punishment specifically. Some very basic dimension of dignity's meaning is often presumed to inhabit the sphere of this right; a sense that harm to dignity means treating a human person as if s/he was not a human person (Waldron 2013,4$).{ }^{17}$ Some writers align the idea of dignity in a basic sense with the Kantian-inspired idea of treating a person like an object (Barak 2015, 146-147; Maurer 1999, 288; Riley 2010, 124). Some writers view this 'object formula' approach as of limited value from a legal perspective (Hörnle 2012, 311 ) or as an easy assumption (Waldron 2012, 26-27). Either way, it is not clear how something like the Kantian-inspired object formula might guide decisions in human rights cases about the prohibition of torture's scope. If the idea of dignity as it pertains

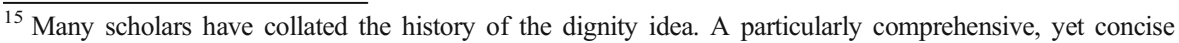
reading is found in Barilan (2012, chapter 2).

${ }^{16}$ Several sources within the body of literature are cited below. Other examples from the past 10 years include Addis (2015), Andorno (2013), Baertschi (2014), Byk (2010), Clements (2011), Daly (2012), Dilley and Palpant (2013), Dupré (2015), Hiskes (2015), Hughes (2011), Jacobson and Silva (2010), Kalb (2011), Kateb (2011), Khaitan (2012), Kirchhoffer (2013), Lee and George (2008), Neal (2014), Pellegrino et al. (2009), Rao (2011) and Schroeder (2012). Two further recent sources, which provide a clear sense of the scope and diversity of the literature and include extensive bibliographies, are Düwell et al. (2014) and McCrudden (2013).

${ }^{17}$ This kind of harm is often understood as something that is intuitively grasped; see, e.g. Shultziner (2007, 86-87). See also Riley, who observes that dignity is "often observed in the breach", continuing, "[t]orture is a prime example of how dignity appears in this way." (Riley 2008, 125).
} 
to the right not to be subjected to torture has a basic meaning, questions remain about what this consists of and what it implies for the right's application.

There are a number of challenges then for making sense of the idea of dignity in interpretation of the right not to be subjected to torture and associated harms: Human rights jurisprudence does not make its understanding of dignity apparent and does not always openly use the language of dignity, mirroring wider human rights discourse; dignity theory literature is a rich resource for helping to understand the dignity idea but is not easy to navigate; the dignity idea might be presumed to have a basic meaning, in a formulation that is insufficient to guide human rights decision-making. In light of these challenges, what meaning should the idea of dignity assume in the context of the prohibition of torture, and, as a prior question, how should this meaning be discerned?

\section{A Methodology for Bridging Practice and Theory of Dignity}

The question of how to make sense of the relevant meaning of the dignity idea presents itself as a methodological one: how should human rights interpreters go about articulating the content of the dignity idea in a way that can best provide tools for understanding the prohibition of torture's interpretative scope? To respond to this question is to put forward a methodological approach. This section puts forward an approach that reaches out to theoretical expressions of the dignity idea but in a way that anchors them in human rights practice. It outlines a justification for this approach, highlights its main constitutive elements and considers how it can meet the challenges of the dignity idea's meaning.

The methodology's starting point is the prohibition of torture's record of application. It focuses firstly on how dignity has played out in past applications of the prohibition, in individual claims under particular human rights instruments before authoritative interpreters of those instruments. This approach is motivated at a basic level by an understanding of the dignity idea's 'meaning' as reflected in the way that the term is used in practice (in the legal context, see Bix 1995; Endicott 2002, 948). It is also motivated by a pragmatic perspective, in the simple sense that any postulated meaning of the dignity idea should be capable of integration into the existing practice setting, so that the idea has potential to be impactful in that setting. It seeks a meaning of the idea that is reflected in, and can remain realistically anchored within, existing applications of the right.

This approach to making sense of the dignity idea might be described as constructive: It seeks an understanding that can be incorporated into an existing interpretive context, and it is orientated towards productive, practicable outcomes. This label evokes constructive interpretation in law more broadly, associated with Ronald Dworkin's understanding of legal interpretation. The particular advantage of evoking this association is that constructive interpretation is understood to engage with moral and social values (Dworkin's "community morality" (1977, 123-130)). The method advocated here is constructive in the sense that it is inherently open to integrating 'extra-legal' sources. It echoes Beitz's approach to understanding the idea of dignity (noted above), which involves looking for input from beyond human rights discourse $(2013,270)$. The method is dynamic, open to moving back and forth between the reality of dignity in practice and theoretical conceptualizations. 
The methodology is an interpretive one. Ascribing meaning to the term dignity found in prohibition-of-torture jurisprudence is a form of human rights interpretation. In the human rights field, interpretation has as its most obvious object the written text of the rights themselves, but the exercise of deriving meaning from human rights case law is equally one of interpretation (Barak 2005, 3, 11; Bos 1984, chapters vi and vii; Raz 1996, 362). The object of interpretation in the suggested approach is the term dignity in prohibition of torture jurisprudence.

This approach of constructive human rights interpretation entails a relationship between a practice-based, and a theory-based, perspective on the idea of dignity that works in two directions but that ultimately refers to the former. It understands human rights practice to be receptive to conceptualizations of the social value of dignity. It presumes that authoritative interpreters who invoke the dignity idea when applying the right not to be subjected to torture do so with the intention that it should in some sense reflect this broader social value; that prohibition-of-torture dignity is connected to the social value of dignity. In this sense, practice-based human rights law perspectives are open to communicating with theoretical perspectives. At the same time, this approach entails that theoretical conceptualizations of the dignity idea are incorporated within the special constraints of legal decision-making. They will be moulded by the limited parameters of human rights law claims and the need for relevant concepts to be instantly applicable to particular sets of facts. The ensuing benefit is that this methodological lens brings to an understanding of the dignity idea a pragmatic urgency; interpreters cannot afford to become lost in abstract conceptualizations (Cane makes a similar point about legal 'versions' of moral concepts $(2002,12))$. The approach of constructive human rights interpretation views the body of jurisprudence on the application of the right not to be subjected to torture as its own ultimate point of reference for what dignity means in this context. 'Making sense' of the dignity idea means arriving at a picture of the dignity idea's meaning that reflects its micro-context (its sphere of application) and its macro-context (the wider social backdrop to its sphere of application), but the former will be the ultimate reference point for determining the dignity idea's relevant meaning.

\section{Making Sense of Dignity's Meaning: a Model}

This section aims to show how practical and theoretical perspectives can reinforce each other in a way that allows for the development of a practice-rooted yet conceptually rich way of talking about the dignity idea's meaning, which has the potential to inform decisions about the prohibition of torture's scope of interpretation. It thereby models the constructive approach to interpreting the dignity idea.

When this approach is put into practice, it must confront the special challenges of dignity's meaning. Firstly, it involves piecing together use-examples. However, the examples in the context of the right not to be subjected to torture, cruel, inhuman or degrading treatment or punishment are pictures of dignity violated, detached from a way of positively articulating the relevant content of the dignity idea. This echoes the absence of an expressed positive articulation of dignity's meaning in wider human rights discourse. Secondly, the use-examples must be fleshed out by drawing dynamically upon broader sources (theoretical conceptualizations of the dignity idea), but 
these sources are themselves difficult to navigate and often seem either too complex or too basic. It is not clear how to move from the limited substance of the dignity idea visible in case law, to a way of expressing the substance of the dignity idea that can inform the prohibition of torture's application.

This section indicates how a constructive human rights interpretation approach can overcome these challenges. Although a more wide-ranging exercise is desirable, it aims to model the approach by way of example. It offers a case study of prohibition-oftorture case law, followed by a discussion of some theoretical conceptualizations of the dignity idea and a suggestion for mediating between practical and theoretical perspectives.

\section{A Case Study of Dignity in Practice: Dignity harm in ECHR Jurisprudence}

This part of the discussion looks to the jurisprudence of Article 3 ECHR as an illustrative case study of how dignity plays out in interpretation. It aims to go a step further than acknowledging when the ECtHR invokes the idea of dignity; it aims to distil something about interpreters' perceptions of the substantive content of the idea by spotlighting the nature of the suffering that the Court has judged to align with the scope of the right's terms and to give rise to Article 3 violations.

The starting point is the Strasbourg Court's perceived oppositional relationship between the idea of dignity and the harm proscribed by the right in Article 3. The jurisprudence shows a polarity between dignity and Article 3 harm that conforms to common intuitions that torture, inhumanity and degradation are the antithesis of respect for human dignity. For example, the ECtHR has stated that

[...] [T]he Court finds that the conditions which the applicant was required to endure were an affront to human dignity and reached the threshold of degrading treatment for the purposes of Article 3.

When a person is confronted by the police or other agent of the State, recourse to physical force which has not been made strictly necessary by the person's own conduct diminishes human dignity and is in principle an infringement of the right set forth in Article 3 of the Convention $[\ldots]^{18}$

The Court has stated that "[...] treatment [...] may be incompatible with the standards imposed by Article 3 in the protection of fundamental human dignity [...]" 19 and " $[. .$.$] the State must ensure that a person is detained in conditions which are$ compatible with respect for his human dignity [...]". ${ }^{20}$ It has stated that treatment has "undermined" dignity, that it has "stripped" an individual of dignity, ${ }^{21}$ that it has

\footnotetext{
${ }_{18}$ M.S. v. The United Kingdom, 24527/08, 03 May 2012, para. 45, and Rizvanov v. Azerbaijan, 31805/06, 17 April 2012, para. 49 respectively. For further examples see Iwanczuk v. Poland, 25196/94, 15 November 2001, para. 59; M.S.S. v. Belgium And Greece [GC], 30696/09, 21 January 2011, para. 263; Yudina v. Russia, 52327/ 08, 10 July 2012.

${ }^{19}$ Keenan v. United Kingdom, 27229/95, 03 April 2001, para. 113.

${ }^{20}$ McGlinchey and Others v. United Kingdom, 50390/99, 29 April 2003, para. 46.

${ }^{21}$ Piechowicz v. Poland, 20071/07, 17 April 2012, para. 141.
} 
"diminished" dignity, ${ }^{22}$ that it has not been "respectful" of dignity ${ }^{23}$ and that Article 3 harm can occur where an individual feels "hurt in his dignity". ${ }^{24}$ As early as the 1978 Tyrer case, the Court described the protection of dignity as "one of the main purposes of Article 3". ${ }^{25}$ The Strasbourg Court perceives proscribed Article 3 harm as the diametric opposite of respect for dignity.

In light of a dignity/proscribed harm binary, the case law includes a spectrum of practical ways in which the Convention's interpreters materialize their perceptions of how human dignity is harmed. Practices that are incompatible with Article 3 are linked to the written text of the Convention through the Court's 'definitions' of torture, inhuman and degrading treatment-harm can be described as torture when it is considered to be deliberate inhuman treatment causing very serious and cruel suffering; harm can be inhuman if it is, inter alia, premeditated, applied for hours at a stretch and causes intense physical and mental suffering; harm that is degrading is brought about by feelings of fear, anguish or inferiority capable of humiliating or debasing a person, that breaks a person's physical or moral resistance, drives a person to act against will or conscience or has an adverse effect on personality. ${ }^{26}$ These definitions give some shape to the dignity picture in Article 3. This picture is rooted, however, in the concrete circumstances in which the dignity idea plays out. The examples of dignity harm below intend to provide a detailed picture of the range of situations that the ECtHR has identified as giving rise to Article 3 violations, ${ }^{27}$ focusing on what each case indicates about the kinds of practices that the Court sees as capable of bringing about harm that amounts to torture or to treatment that is inhuman and/or degrading. ${ }^{28}$ This range of situations will inform the subsequent discussion of theoretical perspectives on dignity.

Deprivation-of-liberty contexts (during arrests and in prisons, police stations, immigration centres and health care settings) are often, but not exclusively, the backdrop for 'environmental' dignity harms under Article 3. Harms include being confined to a severely overcrowded space leading to sleep deprivation, being subjected to constant lighting, not being allowed adequate ventilation, suffering overheating, sharing a confined space with insects and pests and being obliged to eat close to toilets. Being compelled to use squalid and/or exposed sanitary arrangements is a recurrent feature of cases in which the Court finds a violation of Article 3. ${ }^{29}$ Poor sanitary arrangements have extended to being deprived of personal hygiene products, such as toothbrushes. ${ }^{30}$

\footnotetext{
22 Salikhov v. Russia, 23880/05, 03 May 2012; M.S. v. The United Kingdom, para. 44.

${ }^{23}$ Sochichiu v. Moldova, 28698/09, 15 May 2012, para. 40.

${ }^{24}$ Mouisel v. France, 67263/01, 14 November 2002, para. 48.

${ }^{25}$ Tyrer v. United Kingdom, para. 33.

${ }^{26}$ Ireland v. United Kingdom, judgment of 18 January 1978, Series A, no. 25, para. 167.

${ }^{27}$ Examples are drawn from cases in which a violation of Article 3 was found. It would also be possible to look at cases that did not arrive at a finding of a violation, for example because responsibility of the respondent state was not engaged, but nevertheless say something about how the Court understands harm to dignity through certain practical examples.

${ }^{28}$ It is sometimes difficult to pin down how the dignity harm is constituted. See, e.g. Mubilanzila Mayeka and Kaniki Mitunga v. Belgium, 13178/03, 12 October 2006; in this case the Court refers to both action and omissions by the Belgian state, and it is not clear what the inhuman treatment is - the fact of the young applicant's detention, and/or the conditions in which she was detained? There is also sometimes a cumulative aspect to situations of dignity harm, which the overview in this section aims to capture.

${ }^{29}$ Kalashnikov v. Russia, 47095/99, 15 July 2002; Peers v. Greece, 28524/95, 19 April 2001; Price v. United Kingodm, 33394/96, 10 July 2001.

${ }^{30}$ Melnitis v. Latvia, 30779/05, 28 February 2012.
} 
The Court has condemned physical and psychological intrusion. It has aligned subjection to strip searches, repeatedly, or accompanied by aggravating factors, with harm to dignity. For example,

Obliging the applicant to strip naked in the presence of a woman, and then touching his sexual organs and food with bare hands showed a clear lack of respect for the applicant, and diminished in effect his human dignity. ${ }^{31}$

The Court has further condemned insult and derision that aggravated a strip-search situation. ${ }^{32}$ In Yankov v. Bulgaria, concerning the forced shaving of a prisoner's hair, dignity harm derived from suffering an involuntary, publicly visible change in physical appearance. ${ }^{33}$ The Court has condemned being forcibly administered drugs under physical restraint for the purpose of obtaining evidence of crime $^{34}$ or being forced to undertake psychiatric treatment after arrest. ${ }^{35}$ Dignity harm has often derived from gratuitous restraint, using chains ${ }^{36}$ or belts, ${ }^{37}$ and from being publicly displayed wearing handcuffs or a hood (including in front of family members and acquaintances) 38 or being placed in a cage (including in front of family members and judicial officers). 39 The Court has aligned dignity harm with being deprived of mental and physical stimulation likely to diminish "mental faculties and social abilities" 40 as a result of prolonged deprivation of human contact, ${ }^{41}$ and mental anguish caused by fear of a death sentence after an unfair trial, ${ }^{42}$ and latterly a death sentence in itself. ${ }^{43}$

The Court has suggested dignity harm to lie in "insecurity and helplessness". 44 Features of Article 3 case law include being deprived of food on the day of a court appearance, ${ }^{45}$ being prohibited from addressing one's family in one's mother tongue and being transported to court hearings in overcrowded conditions, including being compelled to sit on the laps of other prisoners, ${ }^{46}$ or in circumstances not adapted to additional needs, including for wheelchair users. ${ }^{47}$ In Davydov and Others v. Ukraine,

\footnotetext{
$\overline{31}$ Valasinas $v$. Romania, 44558/98, 24 July 2001. See also the Court's comments on forcibly stripping a woman, deprived of liberty, in the presence of male staff in Wiktorko v. Poland, 14612/02, 31 March 2009, para. 53-54.

${ }^{32}$ Iwanczuk v. Poland, 25196/94, 15 November 2001, para. 59.

${ }^{33}$ Yankov v. Bulgaria, 39084/97, 11 December 2003; see also Members Of The Gldani Congregation Of Jehovah's Witnesses And Others v. Georgia (71156/01, 03 May 2007, para. 18) in which one applicant's hair was shaved in a religiously motivated attack that was recorded on film.

${ }^{34}$ Jalloh v. Germany, 54810/00, 11 July 2006.

35 Gorobet v. Moldova, 30951/10, 11 October 2011.

${ }^{36}$ E.g. Hénaf v. France, 65436/01, 27 November 2003; Avci and Others v. Turkey 70417/01, 27 June 2006.

37 Wiktorko v. Poland, 14612/02, 31 March 2009.

${ }^{38}$ Erdoğan Yağiz v. Turkey, 27473/02, 06 March 2007.

${ }^{39}$ See respectively Petyo Petkov v. Bulgaria, 32130/03, 07 January 2010 and Piruzyan v. Armenia, 33376/07, 26 June 2012.

${ }^{40}$ Glowacki v. Poland, 1608/08, 20 October 2012, para. 90.

${ }^{41}$ A.B. v. Russia, 1439/06, 14 October 2010; Piechowicz v. Poland, 20071/07, 17 April 2012; Razvyazkin v. Russia, 13579/09, 03 July 2012.

${ }^{42}$ Koktysh v. Ukraine, 43707/07, 10 December 2009.

43 Al-Saadoon And Mufdhi v. The United Kingdom, 61498/08, 02 March 2010 (see, in particular, para. 137).

44 Slyusarev v. Russia, 60333/00, 24 April 2010, para. 36.

${ }^{45}$ Moisejevs v. Latvia, 64846/01, 15 June 2006.

${ }^{46}$ Khudoyorov v. Russia, 6847/02, 08 November 2005.

${ }^{47}$ Engel v. Hungary, 46857/06, 20 May 2010.
} 
dignity harm stemmed from being used in staff training exercises in a prison, during which physical abuse and insults were common. ${ }^{48}$ Being deprived of a personal set of clothing, and habitually expected to wear whichever clothes the authorities decided to re-allocate, contributed to dignity harm in the care home case of Stanev v. Bulgaria. ${ }^{49}$ Dignity harm has repeatedly resided in situations of insufficient medical care when deprived of liberty. ${ }^{50}$ The Court has emphasized that authorities have waited too long before seeking medical care, have failed to take proper records of treatment and/or have responded negatively to treatment requests. ${ }^{51}$ Harm has been brought about by authorities' failure to take seriously repeated requests for medically necessary aids $s^{52}$ or requests to be moved from an environment that induces deterioration of already-poor health. ${ }^{53}$

Within and beyond deprivation-of-liberty settings, dignity harm is found in the unwarranted use of physical force, with or without long-term consequences. ${ }^{54}$ The Court notes aggravating factors where present. For example, in Sochichiu v. Moldova, it observed

Besides the brutal force used against the applicant, the Court notes from the video of the arrest that the conduct of the police officers was far from being respectful of the applicant's dignity. In particular, one of the police officers stepped on his head and did not remove his foot, even when brushing his trousers. In the Court's opinion, such conduct is degrading and humiliating. The Court also notes the mocking of the applicant's losing some of his teeth and the swearing by one of the officers. ${ }^{55}$

The Court has condemned the suffering of intentionally inflicted severe physical and verbal abuse, including witnessing the abuse of children, other family and community members. ${ }^{56}$ This has included witnessing the destruction of one's home and possessions 57 and being trampled upon after being forced to the ground (in view of loved ones). ${ }^{58}$ In Members of the Gldani Congregation of Jehovah's Witnesses and Others v. Georgia, the violence was exacerbated by the recording and broadcasting of the attacks. ${ }^{59}$ Dignity harm has included being threatened with violence and witnessing extrajudicial executions of relatives and community members. ${ }^{60}$ It has been characterized by the suffering of prolonged physical and verbal bullying. ${ }^{61}$

\footnotetext{
${ }^{48}$ Davydov And Others v. Ukraine, 17674/02, 39081/02, 01 July 2010.

49 Stanev v. Bulgaria, 36760/06, 17 January 2012.

${ }^{50}$ Some examples are Nevmerzhitsky v. Ukraine, 54825/00, 05 April 2005; Ukhan v. Ukraine, 30628/02, 18 December 2008; Kaprykowski v. Poland, 23052/05, 03 February 2009.

${ }^{51}$ E.g. McGlinchey and Others v. United Kingdom, 50390/99, 29 April 2003.

52 Slyusarev v. Russia, 60333/00, 24 April 2010 (authorities' failure to return or provide glasses for poor eyesight).

${ }^{53}$ Elefteriadis v. Romania, 38427/05, 25 January 2011 (authorities' placing of applicant with a lung condition in a cell with smokers).

54 See respectively, e.g. Muradova v. Azerbaijan, 22684/05, 02 April 2009 and Barbu Anghelescu v. Romania, 46430/99, 05 October 2004.

55 Sochichiu v. Moldova, 28698/09, 15 May 2012, para. 40.

${ }^{56}$ Members Of The Gldani Congregation Of Jehovah's Witnesses And Others v. Georgia, 71156/01, 03 May 2007.

${ }^{57}$ E.g. Yöyler v. Turkey, 26973/95, 24 July 2003; Hasan İlhan v. Turkey, 22494/93, 09 November 2004.

58 Ahmet Ozkan and Others v Turkey, 21689/93, 06 April 2004.

${ }^{59}$ Members Of The Gldani Congregation Of Jehovah's Witnesses And Others v. Georgia, para. 105.

${ }^{60}$ Musayev And Others v. Russia, 57941/00, 58699/00, 60403/00, 26 July 2007.

${ }^{61}$ Đorđević v. Croatia, 41526/10, 24 July 2012.
} 
Harm to dignity beyond deprivation of liberty situations has often consisted in suffering indifference. Individuals have suffered indifference in the face of severe mental anguish and repeated requests for information ${ }^{62}$ and in the face of an urgent need for medical attention. ${ }^{63}$ In medical-related cases, dignity harm has stemmed from wilful, manipulative obstruction of requests for access to prenatal genetic testing ${ }^{64}$ and lawful abortion. ${ }^{65}$ In medical cases like these, dignity harm appears also to derive from being effectively made to act against one's will. ${ }^{66}$ Dignity harm has consisted in being obliged to undertake military service at an advanced age without modifications to the service programme ${ }^{67}$ or being forced to undertake physical exercise during military service that knowingly exacerbated a health condition. ${ }^{68}$ The Court has identified dignity harm in situations of indifference on the part of state authorities to one's circumstances of extreme, potentially interminable poverty. ${ }^{69}$ Extreme poverty in M.S.S. v. Belgium and Greece entailed for the applicant "several months, living in the street, with no resources or access to sanitary facilities and without any means of providing for his essential needs". ${ }^{70}$

The detail of these situations conveys dignity harm in practice. Therefore, although human rights law does not explicitly say what the idea of dignity means and Article 3 case law does not explicitly put forward any particular conceptualization, the detail of these situations gives a significant impression of how human dignity is harmed through torture, inhumanity and degradation. Authoritative interpretations of the right are the starting point, and the detail of the case law narrates something significant about the substantive content of human dignity as this idea takes shape through the right's application. A list of instances of dignity harm does not, however, suffice. This list indicates how dignity is harmed, but it does not allow an adequate response to the question of how to articulate the content of the idea of dignity in a way that could be useful in decisions about the interpretive scope of the right not to be subjected to torture and associated harms. A list of past instances of dignity harm needs to be supplemented in a way that can inform questions about the right's scope that are forward-looking.

\section{Conceptual Mapping of the Dignity Idea}

It is not obvious how to move from the limited substance of the dignity idea visible in prohibition-of-torture jurisprudence (point A) to a way of expressing the substance of the dignity idea that can inform application of the prohibition of torture (point B). This is where theoretical conceptualizations of dignity must be called upon. Theorizations of

\footnotetext{
${ }^{62}$ See, e.g. Akkum and Others v. Turkey, 21894/93, 24 March 2005; Luluyev and Others v. Russia, 69480/01, 09 November 2006; Varnava and Others v. Turkey, 16064/90, 16065/90, 16066/90, 16068/90, 16069/90, 16070/90, 16071/90, 16072/90, 16073/90, 18 September 2009; Kadirova And Others v. Russia, 5432/07, 27 March 2012.

${ }^{63}$ Denis Vasilyev v. Russia, 32704/04, 17 December 2009.

${ }^{64}$ R.R. v. Poland, 27617/04, 26 May 2011.

${ }^{65}$ P. and S. v. Poland, 57375/08, 30 October 2012.

${ }^{66}$ This is well summarized in an Amnesty International intervention in the case of P. and S. v. Poland, para. 77.

${ }^{67}$ Taştan v. Turkey, 63748/00, 04 March 2008.

${ }^{68}$ Chember v. Russia, 7188/03, 03 July 2008.

${ }^{69}$ M.S.S. v. Belgium And Greece [GC], 30696/09, 21 January 2011; Rahimi v. Greece, 8687/08, 05 April 2011.

${ }^{70}$ Para. 263.
} 
the dignity idea form a complex web of ideas, which has to be navigated to move from point A to point B. The following discussion approaches theoretical conceptualizations of the dignity idea with a view to facilitating this transition. It focuses on a number of themes that are visible in dignity theory. Doing so provides a map that compresses theoretical conceptualizations of the dignity idea. It does so in order to guide interpreters of the right from the above list of instances of dignity harm towards an interpretation of the dignity idea that could inform interpretive decisions about what should fall within, or be excluded from, the scope of the terms torture, cruel, inhuman and degrading.

Theoretical dignity literature exhibits a degree of "conceptual chaos" (Meltzer Henry 2011, 176), the result of a wide range of approaches and frameworks with diverse starting perspectives, all addressing ostensibly the same thing, ${ }^{71}$ but in the midst of this web of dignity conceptualizations, a number of themes stand out. A number of themes can be seen in theoretical literature, which encapsulate different facets of the dignity idea. The discussion below focuses on three such themes in dignity literature, described as the character of dignity, the dimensions of dignity and the demands of dignity. These are the facets of the idea that can most clearly be moulded into a simple and effective conceptual map.

The character of dignity aligns with the question, what is dignity. This is a preliminary question that is sometimes responded to in a way that says too little (for example, that dignity is 'something that people have') or in a way that says almost too much (for example, that it 'refers to' intrinsic value (Andorno 2009, 233), which seems to go beyond the character of dignity to point towards a substantive underpinning about why dignity is recognized in persons as opposed to what dignity is). The character of human dignity is different to its content. Scholars have variously described dignity as a "normative property" (Birnbacher 1996, 118), a "type of value" (Rosen 2012, 19-23), 72 a "potential" (Pollmann 2010), a "need" (Shultziner and Rabinovici 2012, 107) and also as a "process" (Lickiss 2007, 35). Recently, Waldron has suggested that it is best conceived of as a "status" (Waldron 2013, 24-27), an idea that others have also begun to explore (including Beitz 2013, 283-288). Literature increasingly situates the character of dignity as a conceptually distinct aspect of the idea, and the case study supports this. The references in the case study are to dignity as something that is diminished, shown a lack of respect, hurt, undermined, assaulted and interfered with. In talking about what happens to dignity, the case law implicitly says something about what dignity is. The way that the Strasbourg Court talks about torture, inhuman and degrading treatment suggests that it perceives dignity as some kind of standing, that is able to be diminished, undermined and so on. The case study says something about the way in which certain forms of harm interact with a person's dignity. The characterization of dignity as a 'status', although still a developing idea, is an approach that sits comfortably within the case-study example.

Dimensions of dignity refers to a central conceptual distinction to emerge from theoretical dignity literature. This is a dual conceptual distinction between dignity as

\footnotetext{
${ }^{71}$ One notable difficulty is that writers qualify the idea of dignity in ways that are subtly (yet significantly) different, e.g. dignity "as" or dignity "connotes" (see respectively Shultziner and Rabinovici $(2012,109)$ and Riley $(2008,129)$.

72 In discussion of a Kantian understanding of dignity.
} 
something constant that is acted upon and dignity as something variable that must be realized. This constant/variable distinction is one of several dual distinctions that are associated with the idea of dignity. Some do not relate directly to dignity; rather, they relate to different meanings of the idea (for example, Shultziner's distinction between a thick and a thin meaning of human dignity (2007) or to different orientations of dignity protection (for example, Dupré's distinction between views of human dignity that 'open' inwards or outwards (2009)). ${ }^{73}$ There are other twofold distinctions that relate directly to dignity as something that itself has two dimensions. Andorno has described dignity as having two senses, "ontologique" and "éthique": Dignity has an "ontological' dimension in which it is part of the existence of a human person and as such exists equally amongst persons. Dignity has an 'ethical' dimension in which it is dynamic; it depends on a person's actions and is therefore not possessed in uniform measure by all (1997, 37). This is similar to the way that Maurer describes (the legal principle of) dignity in her insightful study of the ECHR: It has an elemental dimension ('fondamentale') and a realizable or active dimension ('actuée') (Maurer 1999, 5058). Kass refers to "basic" dignity and "full" dignity (2008, 9): Dignity has a basic dimension in which it is foundational and equal amongst human beings $(2008,27)$ and a full dimension in which it can actively flourish as each individual lives her or his life (2008, 19-20). Within the body of literature, it is common to find such dual conceptual distinctions between dignity as something that is acted upon and dignity as something that is realized. These dual distinctions capture the sense that dignity has a narrow dimension that must be safeguarded and a more expansive dimension that has to be realized and promoted through practical measures. The dimension of dignity that is visible in the case study is dignity as an object of harm; it is something (e.g. a standing or status) that can be suppressed. There is little evidence in the case study of the Strasbourg Court condemning failures to promote a positive realization of a person's dignity. The ECtHR also interprets torture, inhuman and degrading treatment or punishment to be prohibited regardless of individual actions. ${ }^{74}$ Article 3 concerns harm to dignity in its narrow dimension.

The literature expresses many understandings of what human dignity is concerned with. These understandings tend to fall into two categories (which can be seen to map onto narrow and expansive dimensions of dignity): respect for dignity implies freedom from certain conditions, and the pursuit of particular states or environments. These aspects constitute the demands of dignity, the requirements that are recognized to flow from dignity. The demands of dignity are crystallized understandings of how dignity is assaulted and how it is promoted. Literature that refers to the way in which dignity is assaulted tends to use the language of 'degradation' and 'humiliation' (e.g. Shultziner 2007; Shultziner and Rabinovici 2012). Often, the literature does not elaborate on these ideas (e.g. Schachter 1983); sometimes it develops them further, as seen, for example, in Shultziner and Rabinovici's substantive understanding of humiliation as injury to (or threat of injury to) a sense of self-worth, where they perceive humiliation as a form of "denial of social recognition" (Shultziner and Rabinovici 2012, 107, 112). Beitz refers to how dignity is assaulted with reference to the destruction of a capacity of self-

\footnotetext{
${ }^{73}$ Dupré advocates a view of dignity that "opens" "inwards, relating to the inner mental and emotional world of the person; and outwards, relating to the person's social and relational identity and being" $(2009,194)$.

${ }^{74}$ Chahal v. United Kingdom, 22414/93, 15 November 1996, para. 79-80.
} 
direction (referring to torture, cruel, degrading treatment, slavery and forced labour) (Beitz 2013, 289). In the bioethics field, Birnbacher's approach suggests that dignity is assaulted by the deprivation of "basic goods": the necessary means of existence, freedom from pain and minimal liberty and self-respect (Birnbacher 1996, 110). Whilst the literature associates a sense of minimal protection with dignity assaults, it associates something more maximal with dignity promotion. It encompasses various approaches to, and ways of expressing, how human dignity is promoted by, for example, empowerment of agents (Beyleveld and Brownsword 2001, 218), respect for individual freedom (Dworkin 1994, 239), individual freedom and social justice (Kelman 1977) and respect for freedom of choice (McDougal et al. 1980, e.g. 465). Dignity literature seems to say two key things that address the substance of dignity: as Shultziner describes these imperatives, "the should" and the "must not" $(2007,77)$. The case study reflects the latter; the domain of Article 3 ECHR is undeniably 'dignityassaulted'.

When the case-study jurisprudence is situated within conceptualizations of the dignity idea, the distinctions around character, dimensions and demands of dignity are most immediately relevant. These distinctions, in light of the case study of dignity harm, lead to a view of dignity as something like an elemental status that can be negatively suppressed (can be the object of suppression) by, for example, injury to a sense of self-worth/destruction of a capacity for self-direction/denial of basic goods. Several questions arise, as will be noted below, but it is the process that is significant in this modelling of the constructive approach to making sense of dignity's meaning - this expression of dignity fits interpretations in which it is used.

This modelling exercise has aimed to situate the meaning of dignity that was extracted from the examples of its use within broader conceptualizations of the idea. It has intentionally avoided trying to assess substantive conceptions of the dignity idea; others are better placed to (continue to) do this work. It has aimed to contribute something different, to take a birds-eye view of some dignity theory literature to inform a practical human rights law perspective. It presents only a snapshot of the literature and focuses on evidencing relevant recurring themes and dichotomies. The literature offers other themes and dichotomies that do not map so immediately onto Article 3 jurisprudence ${ }^{75}$; themes such as the subject of human dignity (the individual versus the community) and the source of human dignity (the question of why dignity is recognized in individuals) do not relate as directly to the content of the idea of dignity that was shown by the case study to play out in the scope of the terms within the right not to be subjected to torture and associated harms. These other themes do, however, point towards further questions, that cannot be addressed here, which might influence in some way the interpretive limits of the right. The three themes of character, dimensions and demands help articulate the substance of the idea of dignity in a way that resonates with the kinds of harm that are visible in the jurisprudence.

The next step is to call upon dignity theorists to further unpack the substance of each of these relevant aspects of dignity's prohibition-of-torture meaning. Only some brief reflections can be given here of what this process of unpacking might entail: For

\footnotetext{
${ }^{75}$ See Egle Venckienè who maps human dignity onto the idea of human beings as 'dichotomous': “[...] human being as a biological-spiritual creature (static feature) and as a social creature (dynamic feature) [...]" $(2011,94)$, and Kass writes that dignity can "shine" or it can be "extinguished" (Kass 2008, 306).
} 
example, to unpack the question of what dignity demands in this context is of obvious value, being at the heart of understanding the scope of meaning of the terms that constitute the right. Ideas like humiliation, injury to a sense of self-worth and denial of a capacity for self-direction are alternative means of expressing how dignity is assaulted. These ideas themselves need to be substantiated, and more needs to be said about which expression best reflects prohibition-of-torture jurisprudence. Birnbacher's approach, which focuses on the deprivation of basic goods, refers to the necessary means of existence $(1996,110)$, something that features in ECHR case law. ${ }^{76}$ Humiliation might also include deprivation of the necessary means of existence, depending on how that idea itself is conceptualized (e.g. Margalit 1996). The ECtHR generally aligns the term humiliation with degrading treatment specifically and not with inhuman treatment, and although more often than not it sees both of these forms as co-existing, there are equally many instances in which it places harm under only one of these headings - is humiliation the most useful term to express how the right as a whole assaults dignity? If assault to dignity is expressed as denial of a capacity for self-direction, does this encompass symbolic harm (Rosen 2012, 96) ${ }^{77}$ More generally, how do torture, cruel, inhuman and degrading treatment differ, if they all protect against assaults to human dignity? Dignity theorists alongside human rights interpreters should focus on a closer look at these demands, as well as dignity's character and dimensions.

A conceptual map of relevant aspects of the dignity idea's meaning can help to move between practical and theoretical perspectives. It has the added advantage of keeping dignity scholars and human rights law interpreters on track to minimize the risk of straying into conceptual territory that is not of direct concern in interpretation of the right not to be subjected to torture and associated harms. This part of the discussion has thereby aimed to model a way of expressing a prohibition-of-torture meaning of the dignity idea that is nuanced, conceptually precise and yet practice-rooted.

\section{Conclusion: Towards an Understanding of Dignity's Meaning in Interpretation of the Prohibition of Torture}

The right not to be subjected to torture, cruel, inhuman or degrading treatment or punishment intends to protect persons in some fundamental sense, and this quality will continue to render questions about the parameters of this right particularly pressing. These parameters are widely accepted to bear some interpretive relation to the idea of dignity, and so it is necessary to make sense of this idea's meaning if interpreters are to take seriously its influence on the scope of the right's terms. As Waldron notes, "loose" usage of the term dignity in some instances can be afforded $(2013,29)$, but in others, this usage would benefit from being tightened up-precision is required when questioning dignity's role in interpretation. With greater precision will come the possibility for interpreters to be able to fully evaluate the relationship between the ideas of dignity and torture, inhumanity and degradation and the implications for individual claims in particular contexts in practice.

\footnotetext{
${ }^{76}$ E.g. M.S.S. v. Belgium and Greece.

${ }^{77}$ On the ideas of symbolism and humiliation, see Jacobson (2009) and Kuch (2010).
} 
This article has explored how interpreters should go about making sense of the content of the idea of dignity with a view to better understanding its influence on interpretive scope. It has proposed a methodological response described as a form of constructive human rights interpretation. This method addresses the special challenges of the idea's meaning: the limited story about dignity's substance that is visible in current authoritative interpretations of the prohibition of torture, overly complex or overly basic theoretical conceptualizations of the dignity idea that are difficult to navigate or apply and the need for a 'map' to help interpreters make sense of the dignity idea, to move from the idea's limited substance that is visible in prohibition-oftorture jurisprudence, to a way of expressing its substance that is capable of illuminating and informing the right's application. Further, this should be a way of expressing dignity's meaning that can not only inform an understanding of dignity's influence on the scope of application of the right to date but which can equally inform questions about its influence on the scope of application of the right in future. The constructive interpretation method is a dynamic approach, which is anchored in human rights practice but, recognizing the limitations of what can be learnt from this practice, looks to theoretical conceptualizations of the dignity idea beyond legal human rights discourse. In modelling this approach, to give an example of how it might look in practice, the article has aimed to integrate the outlines of a story about dignity's meaning found in authoritative interpretations into broader theoretical conceptualizations of the idea. It has done so by focusing on three conceptual themes - of dignity's character, dimensions and demands - which are particularly apt for understanding dignity within the right not to be subjected to torture and associated harms. When dignity is articulated as something like an elemental status that can be suppressed by humiliation, etc., the conceptualization of a basic dignity that tends to be aligned with the prohibition of torture gains more layers. This approach sets up the next level of enquiry that is needed and at the same time limits the sources that are appropriate to inform it. Situating the dignity idea in this way draws lines around the things that can be and, importantly, need to be said about the relevant substance of the idea of dignity. This moves towards a richer understanding of the dignity idea's part in shaping the critical and evolving interpretation of a fundamental right.

Acknowledgments I would like to thank the anonymous reviewers for their valuable comments. Particular thanks are also due to Stephen Tierney for comments on an early overview of this article and to Stewart Cunningham for feedback on a previous draft. Thank you also to research assistant Rebecca McGregor for her efforts in updating the case-law database that informs this article's case study of the European Convention of Human Rights. General thanks are due to my colleague Mary Neal, with whom I continue to spend many thought-provoking hours discussing the topic of human dignity, and to my colleagues who made possible a period of sabbatical leave in 2014.

Open Access This article is distributed under the terms of the Creative Commons Attribution 4.0 International License (http://creativecommons.org/licenses/by/4.0/), which permits unrestricted use, distribution, and reproduction in any medium, provided you give appropriate credit to the original author(s) and the source, provide a link to the Creative Commons license, and indicate if changes were made.

\section{References}

Addis A (2015) Human Dignity in Comparative Constitutional Context: In Search of an Overlapping Consensus ILSA J Int'l \& Comp L 2:1-28 
Andorno R (1997) La Bioéthique et la dignité de la personne. Presses Universitaires de France, Paris

Andorno R (2009) Human Dignity and Human Rights as a Common Ground for a Global Bioethics. Journal of Medicine and Philosophy 34:223-240

Andorno R (2013) Human Dignity and Human Rights. In: A.M.J. ten Have H, Gordijn B (eds) Handbook of Global Bioethics. Springer, Dordrecht, pp 45-57

Baertschi B (2014) Human dignity as a component of a long-lasting and widespread conceptual construct. Journal of Bioethical Inquiry 11:201-211

Barak A (2005) Purposive Interpretation. Princeton University Press, Princeton

Barak A (2015) Human Dignity: The Constitutional Value and the Constitutional Right. Cambridge University Press, Cambridge

Barilan YM (2012) Human Dignity, Human Rights, and Responsibility: The New Language of Global Bioethics and Biolaw. MIT Press, Cambridge MA

Beitz CR (2013) Human Dignity in the Theory of Human Rights: Nothing But a Phrase? Philosophy and Public Affairs 41:259-290

Beyleveld D, Brownsword R (2001) Human Dignity in Bioethics and Biolaw. Oxford University Press, Oxford

Birnbacher D (1996) Ambiguities in the Concept of Menschenwürde. In: Bayertz K (ed) Sanctity of Life and Human Dignity. Kluwer Academic Publishers, Dordrecht, pp 107-122

Bix B (1995) Questions in Legal Interpretation. In: Marmor A (ed) Law and Interpretation: Essays in Legal Philosophy. Clarendon Press, Oxford

Bos M (1984) A Methodology of International Law. Elsevier Science Publishers, Amsterdam

Byk C (2010) Dignity and the moralism of the values expressed by the European Convention on Biomedicine. International Journal of Bioethics 21:61-68

Cane P (2002) Responsibility in Law and Morality. Hart, Oxford

Cassese A (1991) Can the Notion of Inhuman and Degrading Treatment be applied to Socio-economic Conditions? Eur J Int'l L 2:141-145

Clements L (2011) Disability, Dignity and the Cri de Coeur. European Human Rights Law Review 6:675-685

Costa J-P (2013) Human Dignity in the Jurisprudence of the European Court of Human Rights. In: McCrudden C (ed) Understanding Human Dignity. Oxford University Press/British Academy, Oxford, pp 393-402

Daly E (2012) Dignity Rights: Courts, Constitutions, and the Worth of the Human Person. University of Pennsylvania Press, Philadelphia

Dayan C (2007) The Story of Cruel and Unusual. MIT Press, Cambridge MA

Dicke K (2003) The Founding Function of Human Dignity in the Universal Declaration of Human Rights. In: Kretzmer D, Klein E (eds) The Concept of Human Dignity in Human Rights Discourse. Kluwer Law International, The Hague, pp 111-120

Dilley S, Palpant NJ (2013) Human Dignity in Bioethics: From Worldviews to the Public Square. Routledge, New York

Donnelly J (2015) Normative Versus Taxonomic Humanity: Varieties of Human Dignity in the Western Tradition. Journal of Human Rights 14:1-22

Dupré C (2009) Unlocking Human Dignity: Towards a Theory for the 21st Century. European Human Rights Law Review 3:190-205

Dupré C (2015) The Age of Dignity: Human Rights and Constitutionalism in Europe. Bloomsbury/Hart Publishing, Oxford

Düwell M, Braarvig J, Brownsword R, Mieth D (eds) (2014) The Cambridge Handbook of Human Dignity: Interdisciplinary Perspectives. Cambridge University Press, Cambridge

Dworkin R (1977) Taking Rights Seriously. Duckworth, London

Dworkin R (1994) Life's Dominion: An Argument about Abortion, Euthanasia and Individual Freedom. Vintage Books, New York

Endicott TAO (2002) Law and Language. In: Coleman J, Shapiro S (eds) The Oxford Handbook of Jurisprudence and Philosophy of Law. Oxford University Press, Oxford, pp 935-968

Feldman D (1999) Human Dignity as a Legal Value: Part 1. Public Law WIN:682-702

Gearty C (2005) Principles of Human Rights Adjudication. Oxford University Press, Oxford

Hiskes RP (ed) (2015) Human Dignity and the Promise of Human Rights. Open Society Foundations, New York

Hörnle T (2012) Criminalizing Behaviour to Protect Human Dignity. Criminal Law and Philosophy 6:307325

Hughes G (2011) The Concept of Human Dignity in the Universal Declaration of Human Rights. Journal of Religious Ethics 39:1-24 
Jacobson N (2009) A Taxonomy of Dignity: A Grounded Theory Study. BMC International Health and Human Rights 9:3

Jacobson N, Silva DS (2010) Dignity Promotion and Beneficence. Bioethical Inquiry 7:365-372

Kalb J (2011) Litigating Dignity: A Human Rights Framework. Alb L Rev 74:1725-1738

Kass LR (2008) Defending Human Dignity. The President's Council on Bioethics, Washington D. C.

Kateb G (2011) Human Dignity. Belknap Press, Cambridge MA

Kelman HC (1977) The Conditions, Criteria, and Dialectics of Human Dignity - A Transnational Perspective. International Studies Quarterly 21:529-552

Khaitan T (2012) Dignity as an Expressive Norm: Neither Vacuous Nor a Panacea. Oxford Journal of Legal Studies 32:1-19

Kirchhoffer DG (2013) Human Dignity in Contemporary Ethics. Teneo Press, New York

Kuch H (2010) The Rituality of humiliation: Exploring symbolic vulnerability. In: Kaufman P, Kuch H, Neuhäuser C, Webster E (eds) Humiliation, Degradation, Dehumanization: Human Dignity Violated. Springer, Dordrecht

Lee P, George R (2008) The Nature and Basis of Human Dignity. Ratio Juris 21:173-193

Lickiss N (2007) On Human Dignity: Fragments of an Exploration. In: Malpas J, Lickiss N (eds) Perspectives on Human Dignity: A Conversation. Springer, Dordrecht, pp 27-41

Luban D (2015) Human Rights Pragmatism and Human Dignity. In: Cruft R, Liao S M, Renzo M (eds) Georgetown University Law CenterPhilosophical Foundations of Human Rights. Oxford University Press, Oxford, pp 263-278

Margalit A (1996) The Decent Society. Harvard University Press, Cambridge

Maurer B (1999) Le Principe de Respect de la Dignité Humaine et la Convention Européene des Droits de l'Homme. La Documentation Française, Paris

McCrudden C (2008) Human Dignity and Judicial Interpretation of Human Rights. Eur J Int'l L 19:655-724

McCrudden C (ed) (2013) Understanding Human Dignity. Oxford University Press/British Academy, Oxford

McDougal MS, Lasswell, Harold D., Chen, Lung-Chu (1980) Human Rights and World Public Order-The Basic Policies of an International Law of Human Dignity. Yale University Press, New Haven

McGregor L (2014) Applying the Definition of Torture to the Acts of Non-State Actors: The Case of Trafficking in Human Beings. Hum Rts $Q$ 36:210-241

Meltzer Henry L (2011) The Jurisprudence of Dignity. U Pa L Rev 160:169-234

Murtagh KJ (2012) What is Inhuman Treatment? Criminal Law and Philosophy 6:21-30

Neal M (2012) Dignity, Law and Language-Games. International Journal for the Semiotics of Law 25:107122

Neal M (2014) Respect for Human Digntiy as 'Substantive Basic Norm'. International Journal of Law in Context 10:24-46

Nussbaum MC (2004) Hiding from Humanity: Disgust, Shame and the Law. Princeton University Press, Princeton

Pellegrino ED, Schulman A, Merrill TW (eds) (2009) Human Dignity and Bioethics. University of Notre Dame Press, Notre Dame IN

Pollmann A (2010) Embodied Self-Respect and the Fragility of Human Dignity: A Human Rights Approach. In: Kaufman P, Kuch H, Neuhaeuser C, Webster E (eds) Humiliation, Degradation, Dehumanization: Human Dignity Violated. Springer, Dordrecht, pp 243-261

Rao N (2011) Three Concepts of Dignity in Constitutional Law. Notre Dame L Rev 86:183-272

Raz J (1996) Why Interpret? Ratio Juris 9:349-363

Riley S (2008) Observing the Breach: Dignity and the Limits of Political Theology. Law \& Critique 19:115138

Riley S (2010) Human Dignity: Comparative and Conceptual Debates. International Journal of Law in Context 6:117-138

Rosen M (2012) Dignity: Its History and Meaning. Harvard University Press, Cambridge MA

Schachter O (1983) Human Dignity as a Normative Concept. American Journal of International Law 77:848854

Schroeder D (2012) Human Rights and Human Dignity. Ethical Theory and Moral Practice 15:323-335

Shultziner D (2007) Human Dignity_Functions and Meanings. In: Malpas J, Lickiss N (eds) Perspectives on Human Dignity: A Conversation. Springer, Dordrecht, pp 73-92

Shultziner D, Rabinovici I (2012) Human Dignity, Self-Worth, and Humiliation: A Comparative LegalPsychological Approach Psychology. Public Policy and Law 18:105-143

Venckienė E (2011) The Right to Dignity: Terminological Aspects. Jurisprudence 18:91-109

Waldron J (2010) Inhuman and Degrading Treatment: The Words Themselves. Canadian Journal of Law and Jurisprudence 23:269-286 
Waldron J (2012) Dignity, Rank, and Rights/Reply to Commentators. In: Dan-Cohen M (ed) Dignity, Rank, and Rights, The Berkeley Tanner Lectures. Oxford University Press, New York, pp 13-76 and 133-148

Waldron J (2013) Is Dignity the Foundation of Human Rights? NYU School of Law, Public Law Research Paper, New York

Webster E (2011) Degradation: A Human Rights Law Perspective. In: Kaufmann P, Kuch H, Neuhaeuser C, Webster E (eds) Humiliation, Degradation, Dehumanization: Human Dignity Violated. Springer, Dordrecht, pp 67-84 